\author{
Review Article
}

\title{
A PRAGMATIC PLAN FOR THE MENTAL HEALTH CONSEQUENCES DURING COVID-19 PANDEMIC THROUGH AYURVEDA
}

\section{Harshitha K.S1*, Shankar Gautam¹, Ram Kishor Joshi², Ajay Kumar Sahu ${ }^{3}$}

*1PG Scholar, 2 Professor and HOD, Department of Pharmacology, ${ }^{3}$ Associate Professor, Department of

Kayachikitsa, NIA, Jaipur, India.

\begin{tabular}{l} 
Article info \\
Article History: \\
Received: 01-09-2021 \\
Revised : 19-09-2021 \\
Accepted: 25-09-2021 \\
Published: 16-10-2021 \\
\hline KEYWORDS: \\
Ayurveda, \\
Daivavyapashraya \\
Chikitsa, Mental \\
health, Satvavajaya \\
Chikitsa.
\end{tabular}

Chikitsa.

\begin{abstract}
Introduction: Beyond infection, the COVID-19 pandemic has also affected individuals through associated mental illnesses like anxiety and stress and has caused a collateral damage. Ayurveda has described 3 main factors which are responsible for the occurrence of diseases, one of them is Prajnaparadha, which is stated as the main cause for all the mental illness. The threefold treatment principles of Daivavyapashraya, Yuktivyapashraya and Satvavajaya targeting the Ahara, Achara and Chesta is an ideal plan to deal with stress built up in this pandemic.
\end{abstract}

Materials and methods: The Ayurvedic classical textbooks and the peer reviewed articles focusing mental health researches were reviewed. This plan involves the implementation of Daivavyapashraya, Yuktivyapashaya and Satvavajaya based on the exposure and exhibition of symptoms of COVID-19. Daivavyapashraya Chikitsa is employed by Vishnusahasranama recitation/listening, Yuktivyapashraya Chikitsa is employed by the various drugs like Bramhi, Shankapushpi, Ashwagandha etc. and formulations which have psycho-neuroimmune-response, Satvavajaya Chikitsa by the process of counseling.

Results and Discussion: The interdependent nature of immunity and psychological state is already well established and it decides the outcome of disorders. An immune response can be largely affected by mental well-being and mental illness can negatively affect its outcome.

Conclusion: The three fold treatment plan centering the pshycho-neuro-immune action is a complete health promotive, preventive and curative plan and will certainly help in the revival of mental health in the times and after the COVID-19 pandemic.

\section{INTRODUCTION}

The cause of the psychological effects of COVID-19 is likely to be multifaceted. It includes direct effects of viral infections (including brain infections), cerebrovascular disease (including the context of procoagulant status) and level of immune system (e.g. increased levels of inflammatory cytokines and antibody production), The social isolation and stigmaof this potentially dangerous illness causes serious Psychological impact.

\begin{tabular}{|l|l|}
\hline \multicolumn{3}{|c|}{ Access this article online } \\
\hline Quick Response Code & \begin{tabular}{l} 
https://doi.org/10.47070/ijapr.v9i9.2025 \\
\hline
\end{tabular} \\
\hline
\end{tabular}

The immune response to sars-cov-2 infection includes a hyperinflammatory state similar to that observed in haemo phagocytic lymphohistiocytosis where there is an increase in the concentration of the active proteins c, ferritin, and interleukin-6.[1]

The link between inflammation and depression is well-defined and may explain other mental illnesses. [2] Previous epidemiological studies suggest that a variety of neuropsychiatric symptoms may arise in the context of acute viral infection, or after a variety of periods. Reports from the 18th and 19th Century Influenza suggest an increase in the incidence of various neuropsychiatric symptoms, such as insomnia, anxiety, depression, mania, psychosis, and delirium. ${ }^{[3]}$

In SARS and MERS, after recovering from an infection, sleep disturbances, frequent recollection of traumatic memories, emotional debt, impaired 
concentration, fatigue, and dysfunctional memory were reported in more than $15 \%$ of patients in the follow-up period ranging from six weeks to 39 months. ${ }^{[3]}$

Chinese researchers tested psychological responses during the onset of the COVID-19 epidemic in large populations. They found that $53.8 \%$ of respondents rated the psychological impact of emergence as moderate or severe, $16.5 \%$ reported moderate to severe symptoms, and $28.8 \%$ reported moderate and severe anxiety symptoms. ${ }^{[3]} \mathrm{A}$ study in China during the COVID-19 epidemic showed that about $35 \%$ of respondents suffered from depression. ${ }^{4]}$ There were also many research works quoting that negative emotions such as anxiety, depression, and anger increased. ${ }^{[5]}$

\section{AIMS AND OBJECTIVES}

- To address the influence of COVID-19 pandemic on the mental health of the public

- Conceptual study of the Manovikaras w.r.t. Vishada (depression), Chittodwega (anxiety), and Aswapna (insomnia) in the present scenario.

- An approach to propose a pragmatic plan of Ayurvedic intervention for the mental health consequences in three fold treatment plan which includes Daivavyapashraya, Satvavajaya and Yuktivyapashraya Chikitsa.

\section{MATERIALS AND METHODS}

Various research articles from different databases such as PubMed, Scopus, Web of Science, DHARA were reviewed. Articles were searched to establish a connecting link between COVID-19 and Mental health. Ayurvedic textbooks such as Brihatrayees and Laghutrayees were reviewed to study the understanding of mental health disorders and their treatment. Research papers containing the detailed information about the Vishada, Chittodwega and Aswapna; role of Satvavajaya, Daivavyapasharaya and Yuktivyapashraya were studied in detail.

\section{Ayurveda and Manas}

Satva, Atma and Shareera are called Tridanda, a strong support system of the body.[4] The medical system successfully since the ancient times was well aware of the importance of the mind. The definition of Swastha Purusha by Sushrutan includes Prasanna atmaindriya Mana which means that the mind, soul and senses contribute to human health.[5]

Tamas, Rajas, Satva are the three Gunas of the mind, if the balance is lost between them the pathology begins. Charaka's view of life is based on the paradox of the interconnected world. This can be determined by Sharira (body), Indriya (senses), Satva (mind), Atma (Complete consciousness). Vishada and Chittodwega are grouped under Vataja Nanatmaja Vikaras. ${ }^{[6]}$ Nidra is the sumtotal of Tamo Bhava and Kapha dosha and involved Manas in its manifestation [7]. Nidra is also one of the Trayoupastambha which is essential for a healthy life. The features of Vishada can be correlated to depression and Chittodwega with anxiety disorders, Aswapna with insomnia. For all the Manovikaras, Gyana (Atmagyana, knowledge of the self), Vigyana (Shastragyana), Dhairya (Dheerata, Courage), Smriti (Smaranashakti, Memory) and Samadhi (focusing on oneself not the thoughts created by own) are the five important treatment principles. ${ }^{[8]}$

Thus, a critical study of the classics offers certain clinically useful treatment principles and descriptions pertaining to the treatment of Manasavikaras in Ayurveda.

\section{Daivavyapasharya chikitsa}

In ancient Ayurvedic tremors one can find the use of Daivavyapashraya Chikisha. Charaka Samhita employs Daivavyapashraya Chikisa as one of the three therapies mentioned for Sharirikadosha (bodily elements) and Manasikadosha (Psychological attributes). Acharya Chakrapani explains that Daivavya pashraya Chikitsa is the first to be mentioned among the three types of treatment because its mechanism of action cannot be analysed as it acts due to Prabhava (unknown / unexplained action method). ${ }^{[9]}$

- Employed by playing Vishnusahasranama (Vishama jwaraprakarana)/ Shivastotra (Unmadaprakarana)

- Or any Strotra (hymn) known by the patient.

- Chanting done twice daily (morning and evening).

- If not able to chant, it is made to listen twice daily (morning and evening).

\section{Satvavajaya chikitsa[10]}

The word "Sattva" springs from the Sanskrit root "Sat" + "ktva"= Manas. Avajaya- translated as "victory over" or "defeat" which also means to take over or to uplift. These means Satvavajaya is not only victory over mind but it is victory with upliftment of mind (Fig.1) It is achieved by withdrawal of mind from unwholesome Arthas, it consists of Manoartha (Chintya, Vicharaya, Uhya, Dheyaand Sankalpa) and Gyanaartha (Shabda, Sparsha, Rupa, Rasa and Gandha) Ahita (Heena, Mithya and Atiyoga).

In the present era combined medication and psychotherapy have become the most common way to plan psychiatry in the current practice. Satvavajaya involves a process of counseling and empowerment of the individual. Satvavajaya, in short, is a mental exercise designed to carry out the process of guiding a persons mind in dealing with natural stress and calming and balancing emotional stresses. (Table 1)

\section{Yuktivyapashraya chikitsa}

Yuktivyapashraya chikitsa is the logical use of Ahaara and Aushadha.[12] 
Considering the above discussed principles a Pragmatic Plan has been proposed for the management of mental health consequences (Table 2).

\section{Post COVID Management}

- Mridu Panchakarma-Vamana, Virechana, Basti, Nasya

- Shirodhara

- Shirobasti

- Sarvanga Abhyanga followed by Sarvanga Swedana

- Anjana Prayoga

- Dhumapana

Ayurveda Drugs and their Role in Mental Health Disorders

- Brahmi (Bocopa monnieri)- Neuroprotective, effective in acute stress and chronic unpredictable stress, anti-depressive. ${ }^{[11]}$

- Jatamams I (Nardostachys jatamansi)- Stress modifying antioxidant, herbal anxiolytic.[12]
- Tagara (Valeriana wallichi)- Effective against insomnia, antidepressant.[13]

- Vacha (Acoros calamus)- Anti-depressant, effective against neurosis and anxiety.[14]

- Kushta (Saussurea lappa)- antianxiolytic, antidepressant.[15]

- Yashtimadhu (Glycyrrhiza glabra)- Effective in Anidra, antidepressant, anxiolytic.[16]

- Amalaki (Phyllanthus emblica)- Effective in postnatal depression, effective menopausal depression.[17]

- Ashwagandha (Withania somnifera)- Reduces stress, neuroprotective, anti-depressant, anxiolytic.[18]

- Shatavari (Asparagus racemosa)- Anxiolytic.[19]

- Kushmanda (Benincasa hispida)- Anti-depressive, effective in bipolar disorder and obsessive compulsive disorder, effective in generalized anxiety disorder.[20]

Table 1: Treatment principles of Manasika Vikaras (Psychiatric illness) of Ayurveda

\begin{tabular}{|c|c|c|}
\hline Jnana & Adhyatama Jnana & Knowledge of the self and the higher self - Hope \\
\hline Vigyana & Shastra Jnana & $\begin{array}{l}\text { Knowledge about the scriptures, about how to } \\
\text { overcome difficulties, in the present situation the } \\
\text { knowledge about the spread and prevention of } \\
\text { COVID - } 19 \text { - Skill to overcome and face difficulties }\end{array}$ \\
\hline Dhairya & Anannunati Cheatsaha & To be brave, calmness of mind - Courage \\
\hline Smriti & Anubhutartha Smarana & $\begin{array}{l}\text { To think about the other people who are facing the } \\
\text { same and also thinking about the family Support } \\
\text { system - Awareness }\end{array}$ \\
\hline San & $\begin{array}{l}\text { Vishaebhyo Nivartyatmani Manaso } \\
\text { Niyamanam }\end{array}$ & $\begin{array}{l}\text { Not allowing the mind to over think but focus on the } \\
\text { good and the inner self - Focus }\end{array}$ \\
\hline
\end{tabular}

Table 2: Ayurvedic Management of Mansaika Vikaras (Psychiatric illness) in Ayurveda

\begin{tabular}{|c|c|c|c|}
\hline Disease & Unexposed individuals & $\begin{array}{l}\text { Individulas in quarantine / } \\
\text { high risk group }\end{array}$ & $\begin{array}{l}\text { Mild-moderate symptoms of } \\
\text { COVID-19 }\end{array}$ \\
\hline Vishada & $\begin{array}{l}\text { 1. Vachachurna }(3 \mathrm{~g})+ \\
\text { Madhu (q.s) } \\
\text { 2. Brahmi swarasa }(10 \mathrm{ml}) \\
+ \text { Madhu }(10 \mathrm{ml}) \\
\text { 3. Dinacharya+ } \\
\text { Pathyasevana }\end{array}$ & $\begin{array}{l}\text { 1.Vacha Kwatha }(20 \mathrm{ml})+ \\
\text { Kushtachurna }(2 \mathrm{~g})+\text { Madhu } \\
\text { 2.Saraswatachurna }(3 \mathrm{~g}-6 \mathrm{~g}) \\
\text { with Ghrita }(10 \mathrm{ml})+\text { Madhu } \\
(5 \mathrm{ml}) \\
\text { 3. Brahmighrita }(10 \mathrm{~g}) \\
\text { 4.Dinacharya }+ \text { Pathyasevana }\end{array}$ & $\begin{array}{l}\text { 1. Ksheera+ Shatavarichurna } \\
\text { (3g-6g) } \\
\text { 2. Tilataila }(5-10 \mathrm{ml})+ \\
\text { Lashunaswarasa }(10 \mathrm{ml}) \\
\text { 3. Panchagavyaghrita } 10 \mathrm{ml} \\
\text { 4. Vacha Kwatha }(40 \mathrm{ml})+ \\
\text { Kushtachurna }(2 \mathrm{~g})+\text { Madhu } \\
\text { 5. Brahmiswarasa+ Madhu }\end{array}$ \\
\hline Chittodwega & $\begin{array}{l}\text { 1. Kushmandaphalaswarasa } \\
(50 \mathrm{ml})+\text { Kushtachurna } \\
(1 \mathrm{~g})+\text { Madhu }(10 \mathrm{~g}) \\
\text { 2. Kushmandabeejamajja } \\
(10 \mathrm{~g})+\text { Madhu }(10 \mathrm{~g}) \\
\text { 3. Dinacharya }+ \\
\text { Pathyapalana }\end{array}$ & $\begin{array}{l}\text { 1. Kushmandaghrita }(10 \mathrm{~g}) \\
\text { 2. Ashwagandha }(3 \mathrm{~g}-6 \mathrm{~g}) \text { with } \\
\text { Ksheera }(10-15 \mathrm{ml}) \\
\text { 3. Manasamitravataka } 2-2-2 \\
\text { 4. Dinacharya and } \\
\text { Pathyapalana }\end{array}$ & $\begin{array}{l}\text { 1. Kalyanakaghritaprayoga } \\
\text { (10ml) } \\
\text { 2. Brhamighrita }(10 \mathrm{ml}) \\
\text { 3. Ashwagandha Shatavari }(3 \mathrm{~g}) \\
\text { with Ksheera }(10-15 \mathrm{ml}) \\
\text { 4. Kushmandarasayana } 10 \mathrm{~g} \\
\text { 5. Pathyapalana }\end{array}$ \\
\hline Aswapna & $\begin{array}{l}\text { Advise } \\
\text { 1. Vyavama }\end{array}$ & $\begin{array}{l}\text { 1. Tagara 1-1-1 } \\
\text { 2. Brahmivati 1-1-1 }\end{array}$ & $\begin{array}{l}\text { 1. Shirolepa/talam with } \\
\text { Jatamamsichurna }+\end{array}$ \\
\hline
\end{tabular}




\begin{tabular}{|l|l|l|l|}
\hline & 2. Dhyana & 3. Dhyana & \multicolumn{1}{c|}{ Amalakichurna } \\
& 3. Dinacharya and & 4. Vyayama & 2. Shatavari + Ashwaganda \\
Pathyapalana & 5. Dinacharya and Pathya & with Ksheera \\
& 4. Tagara 1-1-1 & palana & $\begin{array}{l}\text { 3. Brahmivati 1-1-1 } \\
\text { 4. Dhyana }\end{array}$ \\
& 5urdhni taila & 5. Murdhni taila & 5athya palana \\
\hline
\end{tabular}

\section{DISCUSSION}

A Pandemic is not just a medical issue, it affects people and the community and causes anxiety, anxiety, depression, depression, stigma and other related factors. The effects of this pandemic on your mental health have not been studied for a long time and are still unknown. Currently, all efforts are focused on understanding clinical features, infectious diseases, transmission mechanisms and management of COVID19 outbreaks. There have been very few concerns expressed about the consequences for one's mental health and discrimination prevention strategies. In this time of extreme crisis the nation's response to the pandemic has raised questions about the mental health and resilience of its people. In the last few decades, there has been growing Ayurveda recognition of clinical practice and research in the field of psychiatry. According to Ayurveda mental health is brought about as a result of harmony between oneself, with others and that of the environment, and influenced by biological and social factors. The vitiation of Mansikadoshas, Raja and Tama and vitiated Dhi, Dhriti and Smriti affect the daily routine of people which are the root causes of mental disorders. The mental disorders viz. Unmada (psychosis), Apasmara (convulsive disorder), Apatantraka (hysteria), Atattvabhinivesha (obsession), Gadodvega (hypochondriasis), Chittodvega (anxiety), Vishada (depression) etc. are described in Ayurveda. Daivavyapashraya, Yuktivyapashraya and Satvavajaya are the three major modalities for the treatment of mental disorders the three fold treatment plan upholds these principles and is the need of the hour to calm minds and help us to hold on and fight against the pandemic situation.

\section{CONCLUSION}

The three fold treatment which includes Daivavyapashraya, Satvavajaya and Yuktivyapashraya will definitely be effective in the mental health consequences during and also after the pandemic. The mechanism of Neuro-psycho-immune mechanisms of the drugs and formulations impart complete health which promotes longevity and happiness to the population.

\section{REFERENCES}

1. Rogers JP, Chesney E, Oliver D, Pollak TA, McGuire $P$, Fusar-Poli $P$, et al., Psychiatric and neuropsychiatric presentations associated with severe coronavirus infections: a systematic review and meta-analysis with comparison to the COVID19 pandemic. Lancet Psychiatry. 2020 Jul; 7(7): 611-627. doi: 10.1016/S2215-0366(20)30203-0. Epub 2020 May 18. PMID: 32437679; PMCID: PMC7234781.

2. Schwarzbold, M., Diaz, A., Martins, E.T., Rufino, A., Amante, L.N., Thais, M. E., Quevedo, J., Hohl, A., Linhares, M.N., \& Walz, R. (2008). Psychiatric disorders and traumatic brain injury. Neuropsychiatric disease and treatment, 4(4), 797-816. https://doi.org/10.2147/ndt.s2653

3. Troyer EA, Kohn JN, Hong S. Are we facing a crashing wave of neuropsychiatric sequelae of COVID-19? Neuropsychiatric symptoms and potential immunologic mechanisms. Brain Behav Immun. 2020 Jul; 87:34-39. doi:10.1016/j.bbi. 2020.04.027. Epub 2020 Apr 13. PMID: 32298803; PMCID: PMC7152874.

4. Sher L. COVID-19, anxiety, sleep disturbances and suicide. Sleep Med. 2020 Jun; 70:124. doi: 10.1016/j.sleep.2020.04.019. Epub 2020 Apr 25. PMID: 32408252; PMCID: PMC7195057.

5. Zhao B, Kong F, Aung MN, Yuasa M, Nam EW. Novel coronavirus (COVID-19) knowledge, precaution practice, and associated depression symptoms among university students in Korea, China, and Japan. International journal of environmental research and public health. 2020 Jan; 17(18): 6671.

6. Charak Samhita, Sutrasthanam, Dirghanjivitiy odhyayah, 1/46. Available from: http://niimh.nic. in/ ebooks/echarak (Accessed on 25 November 2020).

7. Sushrutasamhita, Sutrasthanam, Dosha dhatu malakshaya vruddhi vijjaniyadhyayah 15/39(41). Available fromhttp://niimh.nic.in/ebooks/ esushruta (Accessed on 25 November 2020).

8. Charak Samhita, Sutrasthanam, Maharogadhyaya, 20/11. Available from: http://niimh.nic.in/ ebooks/echarak (Accessed on 22April 2021).

9. Charak Samhita, Sutrasthanam, Astouninditeeya adhyayah, 21/35. Available from: http://niimh. nic.in/ebooks/echarak (Accessed on 22April 2021).

10. Charak Samhita, Sutrasthanam, Dirghanjivitiy odhyayah, 1/58. Available from: http://niimh. nic.in/ebooks/echarak (Accessed on 22April 2021) 
11. Charak Samhita, Sutrasthanam, Trisreshaneeya adhyayah, 11/54. Available from: http://niimh. nic.in/ebooks/echarak (Accessed on 22April 2021)

12. Charak Samhita, Sutrasthanam, Trisreshaneeya adhyayah, 11/54. Available from: http://niimh. nic.in/ebooks/echarak (Accessed on 22April 2021)

13. Singh HK, Dhawan BN. Neuropsycho pharmacological effects of the Ayurvedic nootropic Bacopa monniera Linn. (Brahmi). Indian Journal of Pharmacology. 1997 Sep 1; 29(5):359.

14. Purnima BM, Kothiyal P. A review article on phytochemistry and pharmacological profiles of Nardostachys jatamansi DC-medicinal herb. J Pharmacogn Phytochem. 2015; 3(5): 102-6.

15. Toolika E, Ravi M, Bhat NP, Shetty SK, Ravishankar B, Savitha HP. A comparative pharmacological study on the effect of Tagara (Valeriana wallichii) AND Jatamansi (Nardostachys jatamansi) in the management of Anidra WSR to primary insomnia. J Phytopharmacol. 2015; 4: 147-51.

16. Acharya R, Bhatt S, Ashok BK, Ravishankar B. A Comparative Pharmacological Evaluation of Antianxiety Activity of Raw and Traditionally Shodhita (Processed) Rhizome of Vacha (Acorus calamus L.). Journal of Drug Research in Ayurvedic Sciences. 2019;4(1):29-32

17. Madhuri K, Elango K, Ponnusankar S. Saussurea lappa (Kuth root): review of its traditional uses, phytochemistry and pharmacology. Oriental Pharmacy and Experimental Medicine. 2012 Mar; 12(1): 1-9.

18. Kumar S, Dora BB. A Critical Appraisal on Phytochemical Constituents and Therapeutic Effect of Yashtimadhu (Glycyrrhiza glabra). Research \& Reviews: Journal of Medical Science and Technology. 2017; 6(3): 6-10.

19. Das SK, Das A, Das B, Panda P, Bhuyan GC, Khuntia BB. Important uses of Amalaki (Emblica officinalis) in Indian system of Medicine with Pharmacological Evidence. Research Journal of Pharmacology and Pharmacodynamics. 2017 Dec 30; 9(4):202-6.

20. Singh N, Bhalla M, de Jager P, Gilca $M$. An overview on ashwagandha: a Rasayana (rejuvenator) of Ayurveda. African Journal of Traditional, Complementary and Alternative Medicines. 2011; $8(5 \mathrm{~S})$.

21. Singla R, Jaitak V. Shatavari (Asparagus racemosus Wild): A Review on Its Cultivation, Morphology, Phytochemistry and Pharmacological Importance. International Journal of Pharmacy \& Life Sciences. 2014 Mar 1; 5(3).

22. Ahir Y, Tanna I, Shukla VJ, Ravishankar B, Chandola HM. Psycho-neuro-pharmacological evaluation of kushmandadi ghrita. AYU (An international quarterly journal of research in Ayurveda). 2009 Oct 1;30(4): 397.

\section{Cite this article as:}

Harshitha K.S, Shankar Gautam, Ram Kishor Joshi, Ajay Kumar Sahu. A Pragmatic Plan For The Mental Health Consequences During Covid-19 Pandemic Through Ayurveda. International Journal of Ayurveda and Pharma Research. 2021;9(9):86-90. https://doi.org/10.47070/ijapr.v9i9.2025

Source of support: Nil, Conflict of interest: None Declared

\section{*Address for correspondence} Dr. Harshitha K.S

P.G Scholar,

Department of Kayachikitsa,

NIA, Jaipur.

Email:

harshithasathyakumar94@gmail.com

Disclaimer: IJAPR is solely owned by Mahadev Publications - dedicated to publish quality research, while every effort has been taken to verify the accuracy of the content published in our Journal. IJAPR cannot accept any responsibility or liability for the articles content which are published. The views expressed in articles by our contributing authors are not necessarily those of IJAPR editor or editorial board members. 